\title{
Downy Mildew: A Serious Disease Threat to Rose Health Worldwide
}

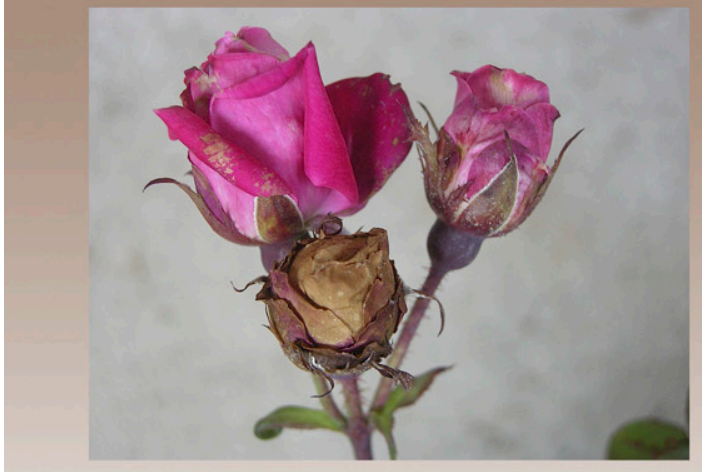

Catalina Salgado-Salazar

Mycology and Nematology Genetic Diversity and Biology Laboratory,

U.S. Department of Agriculture, Agricultural Research Service, Beltsville, MD;

Oak Ridge Institute for Science and Education,

ARS Research Participation Program, Oak Ridge, TN; and

The IR4 Project, Rutgers University, Princeton, NJ

Nina Shishkoff

Foreign Disease/Weed Science Research Unit,

U.S. Department of Agriculture, Agricultural Research Service,

Frederick, MD

Margery Daughtrey

Long Island Horticultural Research and Extension Center,

Cornell University, Long Island, NY

Cristi L. Palmer

The IR4 Project, Rutgers University, Princeton, NJ

Jo Anne Crouch ${ }^{\dagger}$

Mycology and Nematology Genetic Diversity and Biology

Laboratory, U.S. Department of Agriculture,

Agricultural Research Service, Beltsville, MD

During the last 70 years, downy mildew disease affecting plants in the genus Rosa L. (rose) has become a serious problem for growers in the U.S. and many parts of the world, causing significant financial and crop losses every year (Ayala-Vásquez et al. 2008; Baker 1953; Chase and Daughtrey 2013). This disease can be very severe in greenhouses and other protected production systems, but downy mildew is also problematic for field- or container-grown roses outdoors. Outbreaks can occur when inoculum is present and environmental conditions foster disease development in any cultural setting (Horst and Cloyd 2007). All rose cultivars and varieties are susceptible to the disease, although they may differ greatly in their sensitivity (Debener and Byrne 2014). Downy mildew—as with the majority of other major rose diseases-negatively affects the appearance of flowers and foliage, which reduces the value and marketability of the plant (Debener and Byrne 2014). The disease is highly destructive when it strikes, extraordinarily persistent in some regions of the world (e.g., Colombia; Gómez and Arbeláez 2005), but sporadic in its occurrence in other areas depending upon prevailing weather patterns (e.g., California; Aegerter et al. 2003).

Rosa is a genus of woody perennial plants in the family Rosaceae and comprises approximately 190 species (Horst and Cloyd 2007). Roses are one of the most popular and economically important

${ }^{\dagger}$ Corresponding author: J. A. Crouch; E-mail: joanne.crouch@ars.usda.gov

Funding: This work was supported by USDA Specialty Crops Research Initiative grant 2016-51181-25407, USDA Agricultural Research Service projects 8042-22000-298-00-D and 8044-22000-045-00-D, and by an appointment of C. Salgado-Salazar to the ARS Research Participation Program administered by the Oak Ridge Institute for Science and Education (ORISE) through an interagency agreement between the U.S. Department of Energy (DOE) and the USDA. ORISE is managed by ORAU under DOE contract number DE-AC05-06OR23100.

Accepted for publication 7 April 2018.

@ 2018 The American Phytopathological Society environmental horticulture plants, and are grown as garden shrubs, flowering potted plants, and for use as cut flowers (Debener and Byrne 2014). The rose industry has a substantial economic impact on the global economy, comprising a major portion of global floriculture production, valued in 2016 at over $\$ 50$ billion annually (World Floriculture Map 2016). U.S. rose production alone was valued at $\$ 41$ million in 2015 (USDA-NASS 2016).

As with most diseases that affect rose cultivation, there are very few good assessments of the losses incurred due to downy mildew (Debener and Byrne 2014). However, where estimates are available, reported losses due to downy mildew can be staggering. For example, in Colombia, where cut rose exports exceed $\$ 365$ million annually, losses due to outbreaks of downy mildew in the late 1990s were reported to be close to $\$ 5.7$ million (Gómez and Filgueira-Duarte 2012). Ongoing costs to control the disease in Colombia are currently estimated at \$2.3 million annually (Gómez 2014). In South Africa, $100 \%$ crop losses were reported when the disease appeared for the first time in 1996 (Achar 1997). In Kenya, which produces 38\% of all cut roses sold in Europe, downy mildew is responsible for losses of 10 to $12 \%$ annually (Kariuki 2015).

\section{Pathogen}

Rose downy mildew disease is caused by an obligate biotrophic oomycete in the family Peronosporaceae, namely Peronospora sparsa Berk. (syn. P. rubi Rabenh. ex J. Schröt). The pathogen's name reflects the characteristic sparse production of hyaline spores, which appear white to pale gray and crystalline on infected host tissue when viewed with the naked eye (Chase and Daughtrey 2013). In the original report of rose downy mildew, Berkeley described $P$. sparsa sporangia that germinated by zoospores "which burst their common envelope and move about with almost inconceivable rapidity like little infusorial animals by means of lash like threads" (Berkeley 1862). Germination by zoospores is a trait not otherwise found in the genus Peronospora, but it is a defining characteristic of the related genus Pseudoperonospora (Thines and Choi 2016). Some taxonomists have therefore considered the rose downy mildew pathogen as a member of the genus Pseudoperonospora, and even 
proposed that the species be reclassified as Pseudoperonospora sparsa on this basis (Skalicky 1966). However, the sole description of $P$. sparsa zoospores has not been confirmed in the past 155 years, and several histological studies demonstrate that $P$. sparsa sporangia germinate directly by means of a germ tube (Aegerter et al. 2003; Filgueira and Zambrano 2014; Gómez 2014; Gómez and FilgueiraDuarte 2012), consistent with the inclusion of the rose downy mildew pathogen in the genus Peronospora.

\section{Disease Symptoms}

The response of different rose species and cultivars to the downy mildew pathogen varies greatly, making accurate disease diagnosis difficult (Chase and Daughtrey 2013). Downy mildew symptoms can occur on leaves, stems, peduncles, calyxes, and petals. Early symptoms are very difficult to distinguish from nutrition deficiency, spray injury, or black spot disease caused by Diplocarpon rosae (Xu and Pettitt 2004). Symptoms of early stage infection typically include purplish-red, brown, or black leaf spots that may appear square or angular, as the pathogen is often restricted to areas between major leaf veins (Fig. 1; Baker 1953; Xu and Pettitt 2004). P. sparsa does not always sporulate or produce visible signs of its presence on the underside of the leaves like most other downy mildew pathogens; however, under very humid conditions (85 to 100\%), mycelia will form under leaf spots (Baker 1953; Xu and Pettitt 2004), and on some cultivars, sporangiophores are visible on leaves (Fig. 1) and on canes. As the disease develops, leaves may turn yellow and abscise, sometimes with fast and extensive abscission, with a similar outcome to the more gradual leaf drop seen with black spot disease (Baker 1953; Chase and Daughtrey 2013; Xu and Pettitt 2004). In addition, purple patches may form on floral sepals (Gómez and Arbeláez 2005). In rose plants grown as rootstocks, infected cuttings may be defoliated and unable to form roots (Aegerter et al. 2003). Age of canes when infected impacts response: young canes may experience dieback and longitudinal cracking, while older canes fail to reach minimum production size (Aegerter et al. 2003; Gómez and Arbeláez 2005). Collapsing buds or cankers can form on newly emerging rose canes (Chase and Daughtrey 2013) (Fig. 1), and dieback can occur due to the invasion of weakened tissues by secondary pathogens such as Botrytis cinerea (Aegerter et al. 2003).

\section{Host Range}

$P$. sparsa causes downy mildew disease in certain members of the Rosaceae family, namely roses; caneberries such as blackberries, raspberries, and dewberries (Rubus spp.); and cherry laurel (Prunus laurocerasus L.) (Crepel and Inghelbrecht 2002; Farr and Rossman 2017; Koponen et al. 2000). Downy mildew diseases on roses and caneberries were once considered to be caused by two different Peronospora species, solely on the basis of host association, with the pathogens named as $P$. sparsa and $P$. rubi, respectively (Constantinescu 1991). However, cross-inoculations performed in vitro with isolates from rose and blackberry showed that an isolate from either host is capable of infecting the other (Breese et al. 1994). Furthermore, morphological characteristics of Peronospora that infect rose, caneberries, and cherry laurel display a noticeable degree of similarity and phenotypic plasticity, highly influenced by environmental conditions, making the delineation of species by morphological features alone unreliable (Hall and Shaw 1992; Hall et al. 1992). At present, DNA-based comparative studies have not been conducted but are needed to evaluate the genetic relatedness of different host isolates from rose, caneberries, and cherry laurel.

\section{Geographic Distribution}

The rose downy mildew disease caused by $P$. sparsa was first described in England in 1862 (Berkeley 1862). By 1875, the pathogen had reached continental Europe, spreading throughout Italy, Germany, Austria, France, Denmark, Holland, and Russia by the early 1900s, where it continued to move across most of the continent during the 20th century (Baker 1953). The first North American sighting came from California in 1880, with the disease reported on an ongoing basis throughout the United States, Canada (Alfieri 1968; Baker 1953;
Gill 1977), and most recently in Mexico (López-Guisa et al. 2013). Although today $P$. sparsa is considered widespread, just a handful of published reports of $P$. sparsa on rose can be found in the literature. A listing of the geographic distribution of $P$. sparsa is found at CABI Invasive Species Compendium (https://www.cabi.org/isc/datasheet/ 39730), with the pathogen occurring in all major regions of the world where roses are grown, including North America, Asia, Africa, Europe, Oceania, and South America (Bertus 1977; CABI 2016; Francis 1981; Gómez and Arbeláez 2005).

\section{Pathogen Identification and Detection}

Morphological identification. $P$. sparsa can be visualized using light microscopy or by staining infected plant tissue with aniline blue followed by examination with a fluorescent microscope (Aegerter et al. 2002; Breese et al. 1994; Gómez 2014; Gómez and FilgueiraDuarte 2012; Schulz and Debener 2009; Williamson et al. 1998). Characteristic features of $P$. sparsa include haustoria and mycelia that grow intracellularly in the host tissue, forming hyaline dichotomously branched sporangiophores that emerge from stomata on the undersides of leaves (Xu and Pettitt 2004). Sporangiophores have straight trunks that are separated into three to four branches with bifurcated tips measuring on average 300 to $465 \mu \mathrm{m}$ (Fig. 2; Francis 1981; Xu and Pettitt 2004). Typically, one branch curves inward and one is reflexed. Sporangiophores end with infective sporangia that are slightly ovoid, colorless to yellowish-brown, measuring 17 to $24 \times 14$ to $21 \mu \mathrm{m}$ (Xu and Pettitt 2004). Oospores are hyaline or pale yellow colored, 22 to $30 \mu \mathrm{m}$ in diameter, with a hyaline cell wall $2 \mu \mathrm{m}$ thick, forming mostly in the spongy parenchyma of leaves and sometimes in sepals, flowers, buds, stems, and petioles (Fig. 2; Gómez and Filgueira-Duarte 2012).

Molecular identification using DNA and immunology-based assays. DNA-based diagnostic assays can be a valuable tool for rose downy mildew diagnosis, as $P$. sparsa infections may be asymptomatic during early stages of infection, symptomology may be confused with physiological or other disease problems, and visible signs of the pathogen on affected plant parts may not be present. Several molecular assays using PCR technologies are available for detection of $P$. sparsa, all of which make use of some portion of the ribosomal DNA internal transcribed spacer sequence as the detection target (Aegerter et al. 2002; Hukkanen et al. 2006; Lindqvist et al. 1998; Rodríguez-Díaz et al. 2017; Williamson et al. 1998). However, of the five DNA-based assays described for identification of $P$. sparsa, only three have been designed and tested using pathogen samples from rose (Aegerter et al. 2002; Hukkanen et al. 2006; Rodríguez-Díaz et al. 2017).

Two nonquantitative detection assays are capable of detecting $P$. sparsa from plant tissue; these rely on gel visualization of PCR product amplified from species-specific primers (Aegerter et al. 2002; Rodríguez-Díaz et al. 2017). The PCR assay of Aegerter et al. (2002) was specifically designed for use with dormant woody rose rootstocks or bud scions and is capable of detecting as little as 2 pg of $P$. sparsa DNA, even from asymptomatic plant material. The nested-PCR assay of Rodríguez-Díaz et al. (2017), although designed as a tool for detection of $P$. sparsa from blackberry (Rubus sp.), can also detect the pathogen from rose leaves. The detection limit for the nested-PCR assay has not been determined. Although the SYBR-green-based real-time PCR detection assay of Hukkanen et al. (2006) was specifically designed to detect $P$. sparsa from arctic bramble ( $R$. arcticus L.) and boysenberry ( $R$. ursinus $\times R$. idaeus), this tool was also used successfully to detect $P$. sparsa from rose tissue. This assay is highly sensitive, with a detection limit of $37 \mathrm{fg}$ of DNA, and detection from field samples made at just $0.2 \mathrm{ppm}$.

An immunology-based detection assay for $P$. sparsa was described by Schulz and Debener (2007), based on polyclonal antibodies that were raised against soluble cytoplasmic proteins extracted from $P$. sparsa sporangia and sporangiophores. Using enzyme-linked immunosorbent assay (ELISA), a detection limit of $10 \mathrm{ng} / \mathrm{ml}$ was reported from $P$. sparsa solubilized in rose leaf extract. No cross-reactivity was observed with common fungal pathogens such as the causal agents of black spot or powdery mildew disease. 
However, cross-reactivity with protein preparations from Phytophthora infestans occurred, suggesting that the antibodies lacked the level of specificity required for a precise detection assay.

Infrared thermographic imaging. Infrared thermographic imaging is a noninvasive technology recently evaluated for detection of $P$. sparsa from rose leaves before development of visible disease symptoms or signs (Gómez 2014). Thermographic images showed a significant increase in leaf temperature during early stages of infection and a subsequent temperature decline in advanced stages (production of sporangia on leaves) of susceptible rose cultivars inoculated with $P$. sparsa. As early as 2 days post inoculation (dpi), $P$. sparsa-infected leaves showed an increase in temperature that persisted for $\sim 10$ days at the site of inoculation. At the center of the infection court, temperature increases were as high as $1.5^{\circ} \mathrm{C}$ at $7 \mathrm{dpi}$, and $2.0^{\circ} \mathrm{C}$ at 10 $\mathrm{dpi}$, with leaf temperature and disease severity positively correlated. In susceptible cultivars, thermographic images detected $P$. sparsa infection two days sooner than visual examination. Thermographic experiments were performed in vitro (Gómez 2014), so it remains to be seen
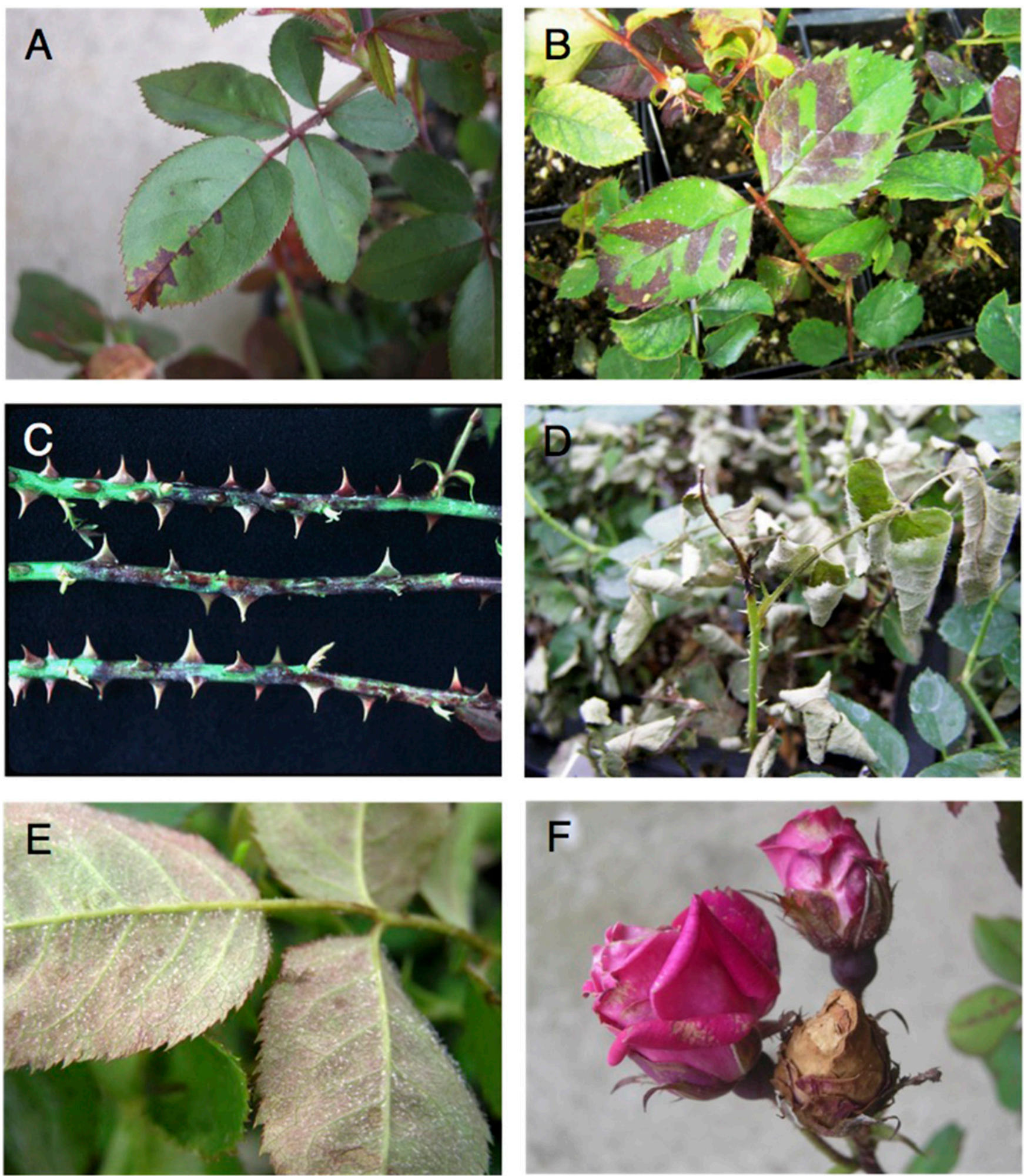

Fig. 1. Downy mildew symptoms caused by Peronospora sparsa on roses. A-B, Purplish-red and brown or black leaf spots. C-D, Reddish purple spots and dieback on rose stems (C photo courtesy of B. Aegerter). E, P. sparsa sporulation on the undersurface of infected leaves. F, Brown spots on petals and damage to young, unopened blossoms. 
if presymptomatic detection can be performed in living plant material and if it would be of practical use in production conditions.

\section{Pathogen Biology, Epidemiology, and the Disease Cycle}

Host infection. An overview of the rose downy mildew life cycle is summarized in Figure 3. P. sparsa rapidly colonizes rose leaf tissue at optimal infection temperatures of 15 to $20^{\circ} \mathrm{C}$ with adequate humidity (85 to 100\%) (Achar 1997; Aegerter et al. 2003; Filgueira and Zambrano 2014; Gómez 2014). Germinated P. sparsa sporangia produce one and sometimes multiple germ tubes (Gómez 2014). Germ tubes can grow as long as $300 \mu \mathrm{m}$ over $24 \mathrm{~h}$, allowing the pathogen to identify optimal locations on the plant surface to initiate infection
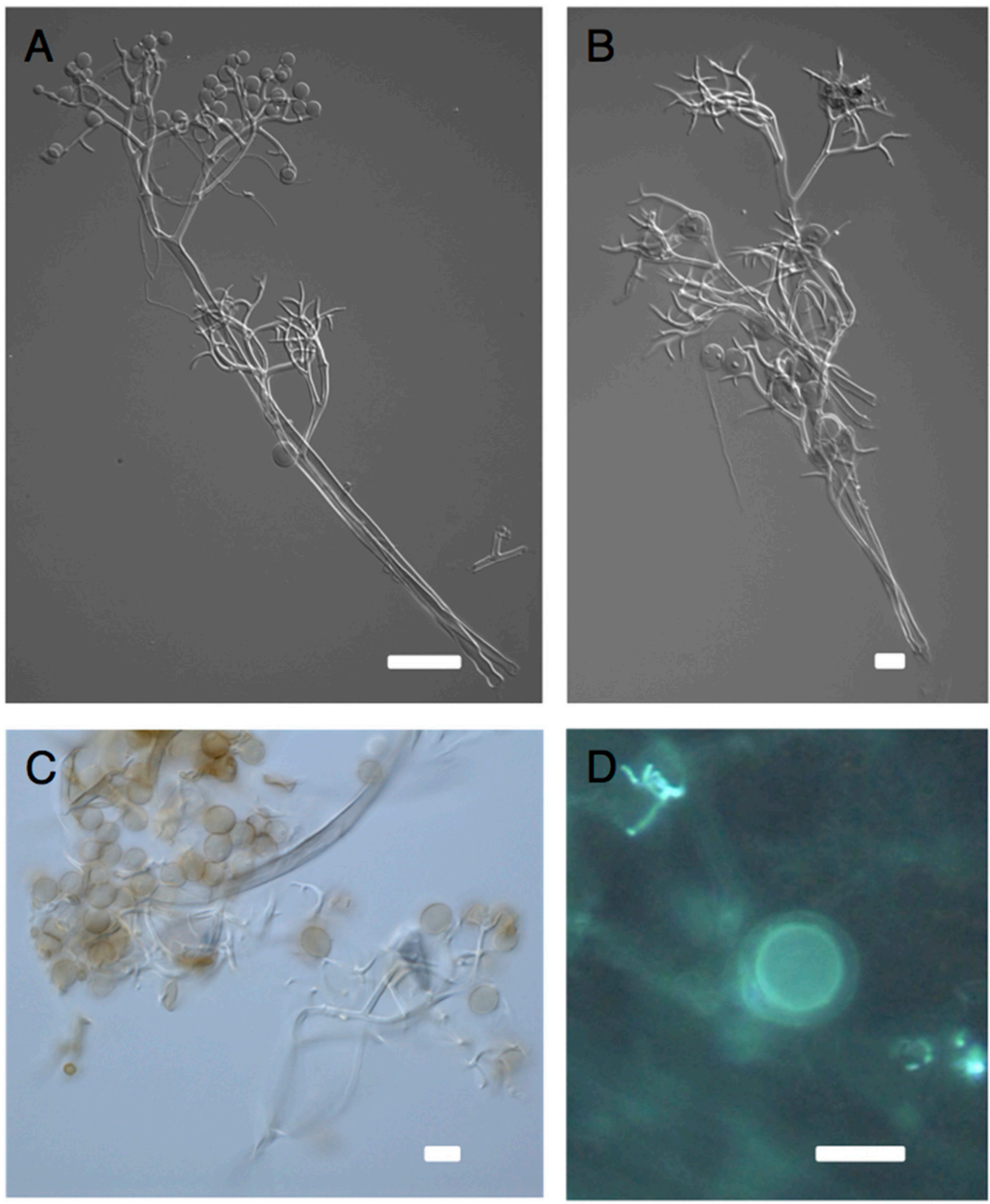

Fig. 2. Peronospora sparsa microscopic features. A-B, Sporangiophores and sporangia. C, Light yellow-brown sporangia. D, Oospore formed within leaf mesophyll (1\% aniline blue stain imaged using epifluorescent microscopy; photo courtesy of B. Aegerter). Scale bars: A $=50 \mu \mathrm{m}, \mathbf{B}-\mathbf{D}=20 \mu \mathrm{m}$. 
(Filgueira and Zambrano 2014; Gómez and Filgueira-Duarte 2012). Appressoria measuring 8 to $10 \mu \mathrm{m}$ form at the terminal end of the germ tube (Gómez and Filgueira-Duarte 2012). Penetration by appressoria on the abaxial surface of young leaves can occur through stomata or directly through the cuticle, occurring 8 to $12 \mathrm{~h}$ after inoculation, respectively (Gómez 2014). Penetration of mature leaves has not been observed (Gómez 2014). During the early stages of infection ( 1 to $5 \mathrm{dpi}$ ), stomatal apertures of susceptible rose leaves are significantly reduced in size or even closed completely (Gómez 2014). Colonization of rose leaves by $P$. sparsa coincides with increased leaf temperature, possibly due to a reduction in leaf transpiration due to stomatal closure (Gómez 2014).

Juvenile rose tissue appears to be far more susceptible to infection by $P$. sparsa than older tissue (Breese et al. 1994; Gómez 2014; Gómez and Arbeláez 2005). Inoculation studies show that $P$. sparsa sporangia germinate on the abaxial surface of young and intermediate age leaves between 2 and 24 h after inoculation (Gómez 2014; Gómez and Filgueira-Duarte 2012). In contrast, on mature leaves, sporangia rarely germinate (Gómez 2014). In addition, mature leaves colonized by $P$. sparsa show very limited hyphal growth (Gómez 2014).

The latency period for rose downy mildew is very short, with disease symptoms observed 4 dpi and sporulation observed at 5 days during trials conducted in California (Aegerter et al. 2003). Similar time frames were documented for rose downy mildew in Colombia and the United Kingdom (Breese et al. 1994; Filgueira and Zambrano 2014; Gómez 2014; Gómez and Arbeláez 2005; Gómez and FilgueiraDuarte 2012). Once inside the young leaf, within $48 \mathrm{~h}$, intracellular hyphae and haustoria produced by $P$. sparsa grow profusely within the spongy parenchyma tissue (Gómez 2014). Host cells remain intact, even after 10 days of infection and extensive haustorial colonization (Gómez 2014). Hyphal growth progresses rapidly, leading to extensive colonization of mesophyll tissue within 5 days, and all tissue types by 6 days (Aegerter et al. 2002; Gómez 2014). By $15 \mathrm{dpi}$, up to $62 \%$ of leaves (from susceptible cultivars) infected by $P$. sparsa may absice, and floral buds may show atypical development and distortion (Gómez 2014).

Sporangiophores emerge from the stomatal openings or directly from stem or flower tissues. In general, under humid, cool conditions, sporangiophores and sporangia of $P$. sparsa can appear in great numbers on the lower surface of leaves and on flower buds and stems under severe disease pressure (Fig. 1). After emergence, sporulation reaches its final stage with production of sporangia. Sporulation, which usually occurs during advanced stages of the disease, coincides with a decrease in leaf temperature, possibly due to water loss from leaf tissue (Gómez 2014). Sporangia may be dislodged and spread short distances by water splash or longer distances by wind currents to nearby plants where the disease cycle starts again. The sporangia of $P$. sparsa can remain viable on dried, fallen leaves for as long as 1 month (Horst and Cloyd 2007).

Overwintering and the source of primary inoculum. Because roses are grown as perennial plants and are largely vegetatively propagated, there is considerable interest in the question of whether or not $P$. sparsa is systemic in the host. Of particular concern is the question of whether the pathogen has the ability to survive as mycelia and/or oospores in rose cuttings and plant roots (Xu and Pettitt 2004). If so, systemic infections would allow the pathogen to be spread through the nursery trade and could facilitate long-term pathogen establishment in the landscape once introduced into an area. The recurrence of rose downy mildew in successive years and the tendency for severe symptoms to appear very quickly after favorable environmental conditions suggests that $P$. sparsa might overwinter within host tissue. However, the overwintering cycle of $P$. sparsa is not entirely understood, and questions about primary sources of inoculum-especially in the production environment - have not been completely addressed.

There is a substantial amount of research that provides evidence that $P$. sparsa undergoes systemic growth within rose vascular tissue, but not all studies support this conclusion. Given the tremendous variation in disease symptomology (Chase and Daughtrey 2013) and the fact that there are literally thousands of different rose cultivars, it is possible that the observed variations may be attributable to the particular host-pathogen-environment interactions unique to each study. Overall, there is consensus that $P$. sparsa hyphae and haustoria grow within leaf tissue parallel to veins, and that the bundle sheath cells of veins are surrounded by hyphae and haustoria (Aegerter et al. 2002; Gómez 2014; Gómez and Filgueira-Duarte 2012; Xu and Pettitt 2004). However, two separate histological studies failed to observe invasion of the vascular system by P. sparsa (Gómez 2014; Xu and Pettitt 2004). In contrast, Gómez and Filgueira-Duarte (2012) showed that leaf veins are colonized by $P$. sparsa, primarily within collenchyma tissue directly under the epidermis, and within bundle sheath cells, with xylem tissue colonized within $48 \mathrm{~h}$. A separate study by Aegerter et al. (2002) provided additional evidence of systemic infection, with microscopic examinations showing that symptomatic rose canes are also extensively colonized within stem cortex tissue by $P$. sparsa hyphae, haustoria, and oospores. It is unknown whether the pathogen colonizes highly lignified tissue found in crown and root tissue (Aegerter et al. 2002).

Antheridia and oogonia form within 3 to 7 days after infection, producing abundant oospores (Fig. 2; Aegerter et al. 2002; Breese et al. 1994; Gómez 2014; Gómez and Filgueira-Duarte 2012; Williamson et al. 1998; Xu and Pettitt 2004). Oospores can be found in the mesophyll of infected leaves and stems (Aegerter et al. 2002; Baker 1953; Breese et al. 1994; Gómez 2014; Gómez and FilgueiraDuarte 2012; Williamson et al. 1998; Xu and Pettitt 2004) and flowers (Cuboni 1888). The regular formation of oospores might be an indication this pathogen is homothallic, but there is no evidence of whether P. sparsa is homothallic or heterothallic (Aegerter et al. 2002; Gómez 2014; Gómez and Filgueira-Duarte 2012). The role of the oospores in pathogen overwintering is not well understood, but some researchers suspect that oospores may be the primary overwintering inoculum (Horst and Cloyd 2007; Xu and Pettitt 2004). This pathogen is also documented from wild roses, which may serve as a reservoir for cultivated roses, but this aspect of the disease cycle has not been studied.

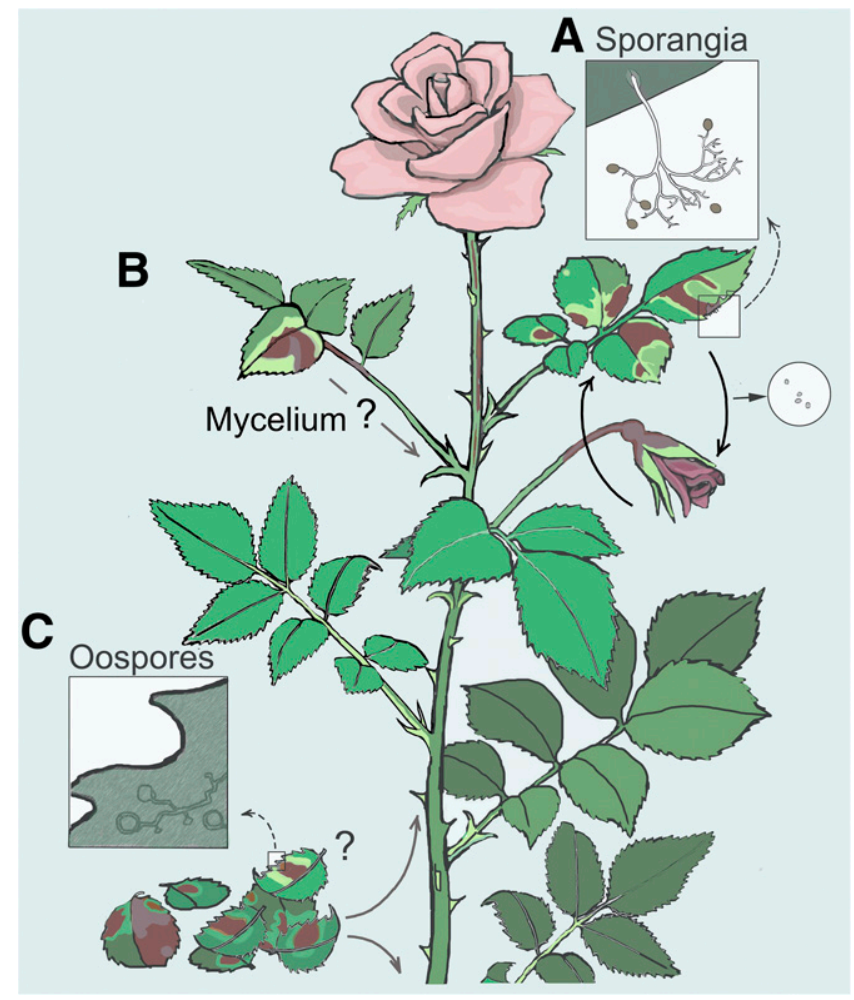

Fig. 3. Proposed life cycle of Peronospora sparsa on roses. A, Sporangia infect leaves, stems, and flowers and spread over the course of a growing season. B, Mycelium travels in tissue to an unknown extent and could possibly overwinter in stems or buds. $\mathbf{C}$, Oospores are produced in plant tissue and might overwinter. 
Studies of overwintering and the sources of primary inoculum to date have been conducted primarily on hybrid tea roses, but the recent growth in the rose industry is from newly-bred shrub roses used for mass landscape plantings, the first of which was the 'Knock Out' family of roses. Rose downy mildew has been recently reported from Knock Out roses (Baysal-Gurel and Simmons 2017a, b; SalgadoSalazar et al. 2018). The impact of the downy mildew on this family and other shrub roses appears to be similar to that on hybrid teas; both groups are susceptible to $P$. spars $a$ under production conditions in greenhouses and field- or in outdoor-grown container roses. Cultivars of shrub roses may vary in susceptibility under moderately conducive conditions, but differences may disappear when conditions for infection and disease development are optimal (A. R. Chase, personal communication).

Environmental conditions influencing pathogen biology and disease. Rose downy mildew disease is significantly impacted by temperature (Aegerter et al. 2003). P. sparsa has not been shown to sporulate at temperatures lower than $6^{\circ} \mathrm{C}$, although sporangia can survive exposure to such temperatures (Aegerter et al. 2003; Filgueira and Zambrano 2014). Germination can occur at temperatures as low as $2^{\circ} \mathrm{C}$ (Breese et al. 1994). Sporulation is favored at 15 to $20^{\circ} \mathrm{C}$, and the highest levels of germination occur at these temperatures as well (Baker 1953; Breese et al. 1994; Filgueira and Zambrano 2014; Giraldo et al. 2002). Information about sporulation levels and germination at higher temperatures is conflicting. Filgueira and Zambrano (2014) observed sporulation at temperatures as high as $33^{\circ} \mathrm{C}$, albeit with reduced numbers of sporangia and with minimal germination success $(\leq 30 \%)$. Other studies showed that germination is reduced drastically at temperatures above $25^{\circ} \mathrm{C}$ (Aegerter et al. 2003; Breese et al. 1994; Horst and Cloyd 2007). All researchers agree that at $35^{\circ} \mathrm{C}$, sporangium production ceases completely (Aegerter et al. 2003; Filgueira and Zambrano 2014). As a result, raising greenhouse temperatures to $30^{\circ} \mathrm{C}$ for three consecutive days has been effectively used to maintain clean stock for cutting production in mini pot roses ( $\mathrm{J}$. Trolinger, personal communication).

Some studies show that $P$. sparsa isolates from different hosts and/ or geographic locations may vary in their response to environmental temperature, suggesting that geographic adaptation may influence optimal temperature requirements for germination (Aegerter et al. 2003; Breese et al. 1994). For example, two $P$. sparsa isolates from California initiated production of sporangia at different times at 15 , 20 , or $25^{\circ} \mathrm{C}$, with sporulation of one isolate occurring approximately 3 days earlier than the second isolate (Aegerter et al. 2003). In contrast, $P$. sparsa isolates from Colombia are consistent in their response to temperature (Varila 2005), which could be due to the clonal population structure characterized from this region (AyalaVásquez et al. 2008).

Roses are almost always unaffected by $P$. sparsa when the humidity is less than $85 \%$ (Horst and Cloyd 2007). Growth chamber experiments have shown that when the temperature is optimal, as little as $4 \mathrm{~h}$ of leaf wetness is sufficient to start the infection process (Aegerter et al. 2003; Baker 1953). For temperatures near $10^{\circ} \mathrm{C}$, at least $8 \mathrm{~h}$ of leaf wetness are required for significant levels of infection (Aegerter et al. 2003).

Light also plays a critical role in the development of $P$. sparsa sporangia, with the conditions found in a typical commercial rose greenhouse favoring sporulation. Photoperiod and light intensity were both shown to significantly impact development of sporangia (Soto and Filgueira 2009). Between 8 and $16 \mathrm{~h}$ of continuous light exposure at light intensities $\geq 560$ lux enhances $P$. spars $a$ sporulation and increases germination (Soto and Filgueira 2009). In contrast, under total darkness or low light (12 h photoperiod, $120 \mathrm{lux}$ ), production of sporangia is minimal, and sporangia are reduced in size (Soto and Filgueira 2009). The presence of high-intensity continuous light is also detrimental to the pathogen. Under constant light exposure (1,000 lux), P. sparsa sporulation is significantly reduced, and sporangia exhibit atypical morphology, reduced size, and lower viability (Soto and Filgueira 2009).

\section{Isolate Storage}

Although sporangia of $P$. sparsa can be germinated on water agar medium (Breese et al. 1994), the pathogen cannot be sustained in culture. Living stocks of the pathogen can be preserved using one of four methods. Isolates of $P$. sparsa can be maintained by inoculating fresh cut leaf disks ( $12 \mathrm{~cm}$ diameter) from susceptible rose cultivars every 10 to 14 days, and incubating at $18^{\circ} \mathrm{C}$ with a $16 \mathrm{~h}$ photoperiod in sealed plastic boxes containing moist cotton wool (Breese et al. 1994). Alternatively, leaf disks with fresh sporangia can be stored at $-70^{\circ} \mathrm{C}$ in sealed plastic boxes for 1 to 4 months without loss of viability (Virányi 1985). A third method uses sporangia suspended in water containing $15 \%$ DMSO, which allows storage at $-20^{\circ} \mathrm{C}$ for up to 6 months without loss of virulence (Schulz and Debener 2007). Long-term storage can be achieved under liquid nitrogen by suspending sporangia in 15\% dimethyl sulfoxide (DMSO) as originally described for Peronosclerospora sorghi (Breese et al. 1994; Gale et al. 1975).

Storage of nonliving samples of $P$. sparsa in herbarium collections is an ideal way to retain important voucher specimens of representative isolates for DNA analyses or morphological assessment. Downy mildew pathogens infecting host tissue are well preserved in herbarium collections, with numerous examples of Peronospora and Plasmopara specimens used for research of pathogen diversity (e.g., Choi et al. 2007; Rivera et al. 2016; Telle and Thines 2008). Protocols for the preparation of herbarium specimens from plant-associated microorganisms are provided in Verkley et al. (2015).

\section{Disease Management}

Disease management strategies for rose downy mildew may shift according to the plant production systems, particularly when environmental conditions are critical for disease development. Roses are grown under a variety of scenarios, with cut flowers and miniature rose potted plants generally produced in greenhouses. The majority of the cut roses destined for U.S. markets are currently grown offshore in South America (Bonarriva et al. 2003). In contrast, hybrid teas and shrub roses that are destined for garden use are generally started by a specialty propagator in a greenhouse as "plugs" and then planted into the field for a year. Some growers start their own vegetatively propagated cuttings ( $\mathrm{K}$. Ong, personal communication). Roses are then bare-rooted and subsequently grown in high tunnels or hoop houses (in the Midwest and northeastern U.S.) until environmental conditions are favorable for them to be moved outdoors. Some roses are sold as bareroot plants, but most are shipped to retail outlets in nursery containers.

Host resistance. Disease resistance is one of the most important traits selected for by rose breeders, as production costs required to maintain high quality flower and foliage appearance and to control disease are very high (Gómez and Filgueira-Duarte 2012). Modern roses are derived from 10 species of Rosa, with the rose genome representing a mosaic of the different progenitor species that provides a diverse gene pool for breeding (Gudin 2000). Traditionally, most rose breeding efforts focused on horticultural traits, and disease resistance characteristics were not emphasized. Increasingly, however, breeding for durable disease resistance has become a priority (Schulz and Debener 2009). Currently, most roses are bred by commercial growers (Debener and Byrne 2014), but some information about resistance to rose downy mildew is publicly available. Multiple sources of resistance to downy mildew have been identified from wild rose germplasm (Schulz and Debener 2007, 2009). Sources of resistance in wild roses could serve as a valuable resource for breeding efforts (Schulz and Debener 2007, 2009), but the markers have not been well characterized, limiting their use in breeding programs (Debener and Byrne 2014).

Cultural practices (Greenhouse, nursery, and landscape). Inspecting incoming plant material for symptoms of rose downy mildew is important for reducing disease losses later on. Growing conditions that avoid the high humidity conducive to downy mildew may be maintained in greenhouses during cut flower or small potted plant production through careful use of heating and fans. Keeping greenhouse humidity below $85 \% \mathrm{RH}$ is key but difficult to achieve under cool, rainy weather conditions. In nursery hoop houses, spacing plants and raising the plastic coverings to allow air movement in the spring can help to reduce the high humidity that favors downy 
mildew outbreaks. With outdoor field or container production, the weather will determine whether conditions are favorable to disease, and there are few effective cultural actions to counteract downy mildew other than growing less susceptible cultivars. Irrigation methods may make a difference: many growers have installed drip irrigation in field or greenhouse to reduce leaf wetness duration. For example, field production in the western U.S. has shifted to buried drip lines in many cases.

Sanitation is critical in all of the different kinds of production arenas: fallen leaves and debris should be collected regularly and buried or burned offsite (Bertus 1977). Infested plant material should never be composted on-site. Downy mildew epidemics happen quickly when conditions are right, and scouting for the first visible signs of an infestation is often not an effective practice. In the landscape, placing roses in full sun rather than partial or full shade, and spacing plants to allow for good air movement between plants can reduce the severity of downy mildew. There are also very large differences in cultivar reaction to downy mildew, so careful observation can lead to elimination of highly susceptible cultivars in the landscape.

Chemical, biological, and biorational controls. To date, management tool options have been limited to chemistry designed to target downy mildews. Products based on plant extracts are generally not effective against this disease, and biological pesticides have not been identified to ameliorate $P$. sparsa on rose except in a case of greenhouse rose production where rose petals were being harvested (A. Chase, personal communication). It has been estimated that $17 \%$ of total fungicide expenditures worldwide go toward the control of downy mildews across all crops (Gisi 2002). Rose downy mildew is treated by regularly spraying with a range of products with differing active ingredients, in rotation. In order to slow the development of resistance, it is highly recommended that label directions are followed closely and that rotations occur among different modes of action as established by the Fungicide Resistance Action Committee (FRAC).

Dithiocarbamate fungicides (e.g., mancozeb) were shown to be effective before the introduction of systemic chemistries (Baker 1953; Bertus 1977), but contact fungicides would now be used only in tank mixes or in alternation with systemic fungicides. O'Neill et al. (2002) reported disease control levels in trials in the U.K. that were superior to mancozeb using high-volume sprays of fosetyl-aluminum and tank mixtures of cymoxanil/mancozeb/oxadixyl/fluazinam; however, not all of these active ingredients are registered in all countries where roses are grown, including the U.S. Phosphonates have also provided effective control of rose downy mildew in commercial greenhouses in South America (Quiroga and Arbeláez 2004). Phenylamides were reported as the key group for control of the disease in 2002 (O'Neill et al. 2002), but this FRAC group (4) is known to be very prone to resistance development in the target pathogen population when used alone and should be used with caution and in accordance with sound resistance management programs. In 2004 and 2006, efficacy trials on greenhouse roses showed excellent control of downy mildew by azoxystrobin (FRAC 11), cyazofamid (FRAC 21), dimethomorph (FRAC 40), mancozeb/copper hydroxide (FRAC M 03/FRAC M 05), mefenoxam (FRAC 4), and phosphonate fungicides (FRAC 33) (Chase and Daughtrey 2013; Palmer and Vea 2016). Efficacy trials conducted in Tennessee in 2016 reported significantly lower downy mildew disease severity and progression in Double Knock Out roses when using spray or drench applications of oxathiapiprolin, a recently developed fungicide included in the new FRAC group 49 (Baysal-Gurel and Simmons 2017a, b; Baysal-Gurel et al. 2017). Home gardeners in the U.S. have access to phosphonates and mancozeb chemistry, and need to understand that some fungicides effective against black spot, rust, or powdery mildew diseases are ineffective against downy mildew (Windham and Windham 2014). As a general rule, strobilurins are not as effective on rose downy mildew as they are for the control of downy mildews affecting other hosts (Chase and Daughtrey 2013).

Besides sporadic efficacy trials, very little has been published since 2002 to explore efficacy with newly introduced modes of action and on newly reported rose downy mildew hosts. Current recommendations for rose downy mildew management rely on protective fungicide treatments with applications on a calendar basis or when symptoms develop. Some growers have learned which seasons of the year are likely to bring downy mildew outbreaks, and spray preventively at those times. Disease management is more effective when full coverage of the underside of the leaves is achieved during contact fungicide treatments or when systemic products such as those in FRAC groups 4, 33, and 49 are employed in rotation.

\section{Discussion}

Much work remains to be done to understand the causal agent of rose downy mildew, even its identity. Are zoospores formed under any circumstances? Is there any reason to think the rose downy mildew is caused by a Pseudoperonospora rather than a Peronospora species? It should be possible to perform a phylogenetic analysis to determine the correct genus for this organism. Are there real taxonomic differences between isolates growing on different rosaceous hosts? A comprehensive taxonomic treatment of downy mildew species on the Rosaceae family is missing. Isolates from different hosts (herbarium and fresh specimens) could be compared for genetic relatedness.

Although it is hard to make meaningful recommendations for altering the landscape environment to make it less hospitable for a pathogen with a worldwide distribution, some research has shown that reducing plant density and shifting row orientation to take advantage of wind movement and sunlight reduces disease (O'Neill et al. 2002). There are clear possibilities for the manipulation of the greenhouse environment. Further work is needed to determine whether altering light levels, photoperiod, temperatures, or exposure to UV would help reduce incidence and spread of downy mildew, and consequently reduce the need for fungicide treatments. Work could also be done to determine if thermographic mapping is practical and could serve as an early detection tool in greenhouses. Previous efforts to develop a disease forecasting system (e.g., Aegerter et al. 2003) accessible to growers should be continued, particularly in the areas where roses are produced. Currently, a great deal of research is being done to look at the effect of UV light on powdery mildew in greenhouse rose production (Kobayashi et al. 2013; Suthaparan et al. 2012). Research is just beginning in the use of UV to control the viability and infectivity of downy mildew pathogens affecting greenhouse cucumbers (Reuveni and Raviv 1997) and tobacco (Sukanya and Spring 2013). It is possible that UV light may be developed as a tool to reduce sporulation in cut rose production.

The majority of the breeding for resistance in roses has been focused on powdery mildew and black spot diseases caused by Podosphaera pannosa and Diplocarpon rosae. Marker assisted selection, RNAi technologies, and genomic and transcriptomic studies of resistance-related genes in both plants and pathogen, could help to identify useful genes that can be used to improve downy mildew disease resistance in roses (Debener and Byrne 2014). Very little is known about pathogen diversity, and how pathogen populations might be structured in different regions of the world, or from different host plants. Mating types for $P$. sparsa are unknown; although some reports suggest the pathogen may be homothallic, evidence is insufficient. The pathogen's genome has not been sequenced yet. Efforts are underway to sequence the genome of cultivated horticultural rose https://www.rosaceae.org, and a draft genome assembly is available for wild rose ( $R$. multiflora) and the medicinal plant $R$. roxburghii (Foucher et al. 2015; Lu et al. 2016; Nakamura et al. 2017). Studies related to the molecular mechanisms underlying host-pathogen interactions are of primary importance in devising effective strategies for disease control.

Despite the importance of $P$. sparsa to the rose industry, its life cycle is still poorly understood. A proper understanding of the disease cycle that includes different kinds of roses (shrub roses versus hybrid teas) could allow for better use of cultural and chemical controls to eliminate it from the landscape. Currently, the role of crop debris in overwintering/spring inoculum has not been determined. If the organism overwinters as oospores or mycelium in plant tissue, pruning or removal of infected plants could eliminate it. 
Understanding whether systemic infection can occur through colonization of vascular tissue would help in making decisions about whether to prune or remove entire infected plants. Further, an investigation of whether systemic infection occurs in some cultivars but not others could lead to the breeding of more tolerant cultivars.

A better understanding of the triggers for the formation of the oospore stage and zoospores (increasing inoculum potential) might lead to better methods of control. Some downy mildew pathogens, such as those responsible for cucurbit downy mildew (Pseudoperonospora cubensis) or grape downy mildew (Plasmopara viticola), require the presence of two mating types for oospores to form (Cohen and Rubin 2012; Wong et al. 2001), while others, like the sunflower downy mildew pathogen (Plasmopara halstedii), are homothallic and regularly produce oospores (Spring 2000). A close relative of downy mildews, Phytophthora capsici, causes pumpkin fruit rot and is heterothallic: if only one mating type infects a field, the pathogen cannot easily overwinter. Gobena et al. (2012) suggested that in the U.S., clonal lineages of $P$. capsici do not survive winter or fallow periods and are not dispersed widely. When an oomycete pathogen does form oospores, however, it may not be possible to replant for many years (Janke et al. 1983; Lamour and Hausbeck 2003) and the genotypes present one year can carry over to the next (Kuznetsova et al. 2010). If $P$. sparsa can overwinter as oospores, sanitation of debris around plants could help reduce the presence of oospores in the soil (Bertus 1977), and mulching over the soil could reduce the movement of inoculum to leaves the next spring.

\section{Acknowledgments}

The authors are grateful to $\mathrm{B}$. Aegerter for providing $P$. sparsa oospore pictures, and to A. Chase, F. Baysal-Gurel, K. Ong, J. Trolinger, and B. Uber for insightful conversations and information on rose production and management of this disease in the U.S. Mention of trade names or commercial products in this publication is solely for the purpose of providing specific information and does not imply recommendation or endorsement by the USDA. The USDA is an equal opportunity provider and employer.

\section{Literature Cited}

Achar, P. N. 1997. First report of downy mildew disease of rose caused by Peronospora sparsa in KwaZulu Natal, Southern Africa. Plant Dis. 81:695.

Aegerter, B. J., Nuñez, J. J., and Davis, R. M. 2002. Detection and management of downy mildew in rose rootstock. Plant Dis. 86:1363-1368.

Aegerter, B. J., Nuñez, J. J., and Davis, R. M. 2003. Environmental factors affecting rose downy mildew and development of a forecasting model for a nursery production system. Plant Dis. 87:732-738.

Alfieri, S. A. 1968. Downy mildew of rose caused by Peronospora sparsa. Plant Pathology Circular \#66. Florida Department of Agriculture, Division of Plant Industry.

Ayala-Vásquez, M., Argel-Roldan, L. E., Jaramillo-Villegas, S., and Marín-Montoya, M. 2008. Genetic diversity of Peronospora sparsa (Peronosporaceae) on rose crops from Colombia. Acta Biol. Colomb. 13:79-94.

Baker, K. F. 1953. Recent epidemics of downy mildew of rose. Plant Dis. Rep. 37: 331-339.

Baysal-Gurel, F., and Simmons, T. 2017a. Evaluation of fungicide drench applications for the control of downy mildew of knockout roses, 2016. Plant Dis. Manage. Rep. 11:OT011.

Baysal-Gurel, F., and Simmons, T. 2017b. Evaluation of fungicide rotations at different application intervals for the control of downy mildew of knockout roses, 2016. Plant Dis. Manage. Rep. 11:OT012.

Baysal-Gurel, F., Simmons, T., Liysnapathiranage, P., and Kabir, M. N. 2017. Evaluation of fungicides for the control of downy mildew of knockout roses, 2016. Plant Dis. Manage. Rep. 11:OT006.

Berkeley, M. J. 1862. Peronospora sparsa. Gard. Chron. 1862:307-308.

Bertus, A. L. 1977. Rose downy mildew. Agr. Gaz. N. S. Wales. 88:8-9.

Bonarriva, J., Jabara, C., and Burket, S. 2003. Industry and trade summary-Cut flowers. U.S. International Trade Commission. 3 June 2013. https://www.usitc. gov/publications/332/pub3580.pdf

Breese, W. A., Shattock, R. C., Williamson, B., and Hackett, C. 1994. In vitro spore germination and infection of cultivars of Rubus and Rosa by downy mildews from both hosts. Ann. Appl. Biol. 125:73-85.

CABI. 2016. Peronospora sparsa datasheet. In: CABI Invasive Species Compendium, https://www.cabi.org/isc/datasheet/39730, accessed September $18,2017$.

Chase, A. R., and Daughtrey, M. L. 2013. Rose Downy Mildew Review. Greenh. Prod. News Mag. 2013:32-34.
Choi, Y. J., Constantinescu, O., and Shin, H. D. 2007. A new downy-mildew of the Rosaceae: Peronospora oblatispora sp. nov. (Chromista, Peronosporales). Nova Hedwigia 85:93-101.

Cohen, Y., and Rubin, A. E. 2012. Mating type and sexual reproduction of Pseudoperonospora cubensis, the downy mildew agent of cucurbits. Eur. J. Plant Pathol. 132:577-592.

Constantinescu, O. 1991. An annotated list of Peronospora names. Thunbergia 15: $1-110$.

Crepel, C., and Inghelbrecht, S. 2002. First record of leaf spots on Prunus laurocerasus in Belgium caused by Phytophthora cactorum and Peronospora sparsa. Plant Dis. 86:563.

Cuboni, G. 1888. La Peronospora delle rose. Statz. Speriment. Agr. Ital. Rome 14: 295-308.

Debener, T., and Byrne, D. H. 2014. Disease resistance breeding in rose: current status and potential of biotechnological tools. Plant Sci. 228:107-117.

Farr, D. F., and Rossman, A. Y. 2017. Fungal Databases, U.S. National Fungus Collections, ARS, USDA. Retrieved November 27, 2017, from https://nt. ars-grin.gov/fungaldatabases/.

Filgueira, J. J., and Zambrano, A. 2014. Temperature effect on rose downy mildew development under environmental controlled conditions. Agron. Colomb. 32:29-35.

Foucher, F., Hibrand-Saint Oyant, L., Hamama, L., Sakr, S., Nybom, H., Baudino, S., Caissard, J. P., Byrne, D. M., Smulder, J. M. S., Desnoyé, B., Debener, T., Bruneau, A., De Riek, J., Matsumoto, S., Torres, A., Millan, T., Amaya, I., Yamada, K., Wincker, P., Zamir, D., Gouzy, J., Sargent, D., Bendahmane, M., Raymond, O., Vergne, P., Dubois, A., and Just, J. 2015. Towards the rose genome sequence and its use in research and breeding. Acta Hortic 1064:167-175

Francis, S. M. 1981. Peronospora sparsa. Page 690 in: IMI Descriptions of Pathogenic Fungi and Bacteria. CAB International, Wallingford, U.K.

Gale, A. W., Schmitt, C. G., and Bromfield, K. R. 1975. Cryogenic storage of conidia of Sclerospora sorghi. Phytopathology 65:828-829.

Gill, D. L. 1977. Downy mildew of roses in Georgia. Plant Dis. Rep. 61:230-231.

Giraldo, S. L., García, C., and Restrepo, F. 2002. Effect of light and temperature on sporangia germination and on the sporulation of Peronospora sparsa Berkeley on rose cultivar Charlotte. Agron. Colomb. 20:31-37.

Gisi, U. 2002. Chemical Control of Downy Mildews. Pages 119-159 in: Advances in Downy Mildew Research. Spencer-Phillips, P. T. N., Gisi, U., and Lebeda, A., eds. Kluwer Academic Publishers, Dordrecht.

Gobena, D., McGrath, M. T., and Lamour, K. 2012. Survival and spread of Phytophthora capsici on Long Island, New York. Mycol. Prog. 11:761-768.

Gómez, S. Y. 2014. Infection and spread of Peronospora sparsa on Rosa sp. (Berk.) - a microscopic and a thermographic approach [doctoral dissertation]. Rheinische Friedrich-Wilhelms-Universität Bonn, Germany.

Gómez, S. Y., and Arbeláez, G. 2005. Effect of temperature on the latency period and production of sporangia of Peronospora sparsa Berkeley on three varieties of rose. Agron. Colomb. 23:246-255.

Gómez, S. Y., and Filgueira-Duarte, J. J. 2012. Monitoring the infective process of the downy mildew causal agent within micropropagated rose plants. Agron. Colomb. 30:214-221.

Gudin, S. 2000. Rose: Genetics and breeding. Plant Breed. Rev. 17:159-189.

Hall, G., Cook, R. T. A., and Bradshaw, N. J. 1992. First report of Peronospora sparsa on Prunus laurocerasus. Plant Pathol. 41:224-227.

Hall, H. K., and Shaw, C. G. 1992. Oospores of Peronospora sparsa Berk. on Rubus species. N. Z. J. Exp. Agric. 10:429-432.

Horst, R. K., and Cloyd, R. 2007. Compendium of Rose Diseases and Pests, 2nd Ed. The American Phytopathological Society, St. Paul, MN

Hukkanen, A., Pietikäinen, L., Kärenlampi, S., and Kokko, H. 2006. Quantification of downy mildew (Peronospora sparsa) in Rubus species using real-time PCR. Eur. J. Plant Pathol. 116:225-235.

Janke, G. D., Pratt, R. G., Arnold, J. D., and Odvody, G. N. 1983. Effects of deep tillage and roguing of diseased plants on oospore populations of Peronosclerospora sorghi in soil and on incidence of downy mildew in grain sorghum. Phytopathology 73:1674-1678.

Kariuki, G. M. 2015. Major diseases of roses in Kenya. HortFresh J. 09/10:39-42.

Kobayashi, M., Kanto, T., Fujikawa, T., Yamada, M., Ishiwata, M., Satou, M. and Hisamatsu, T. 2013. Supplemental UV radiation controls rose powdery mildew disease under the greenhouse conditions. Envrion. Control Biol. 51: 157-163.

Koponen, H., Hellqvist, S., Lindqvist-Kreuze, H., Bang, U., and Valkonen, J. P. T. 2000. Occurrence of Peronospora sparsa (P. rubi) on cultivated and wild Rubus species in Finland and Sweden. Ann. Appl. Biol. 137:107-112.

Kuznetsova, M. A., Ulanova, A. N., Rogozhin, T. I., and Filippov, A. V. 2010 Role of oospores in the overwintering and year-on-year development of the late blight pathogen on tomato and potato. Pages 223-230 in: PPO-Special Report no. 14. Twelfth EuroBlight workshop, Arras, France, 3-6 May 2010.

Lamour, K. H., and Hausbeck, M. K. 2003. Effect of crop rotation on the survival of Phytophthora capsici in Michigan. Plant Dis. 87:841-845.

Lindqvist, H., Koponen, H., and Valkonen, J. P. T. 1998. Peronospora sparsa on cultivated Rubus arcticus and its detection by PCR based on ITS sequences. Plant Dis. 82:1304-1311.

López-Guisa, D., Yáñez-Morales, M. J., and Alanis-Martínez, I. 2013. First report of Peronospora sparsa on Rosa spp. in Mexico. J. Plant Pathol. 95: S4.69-S4.77. 


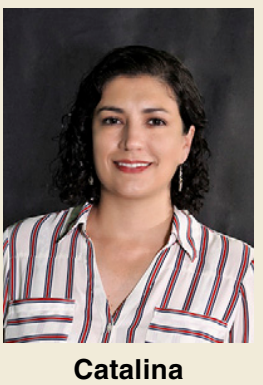

Salgado-Salazar

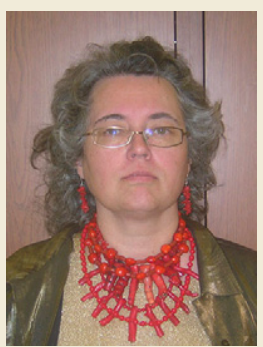

Nina Shishkoff

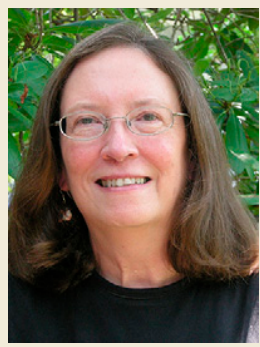

Margery Daughtrey

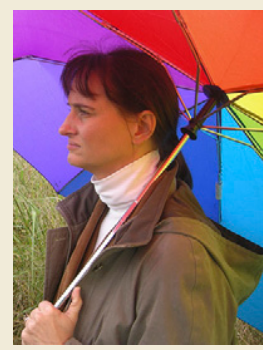

Cristi L. Palmer

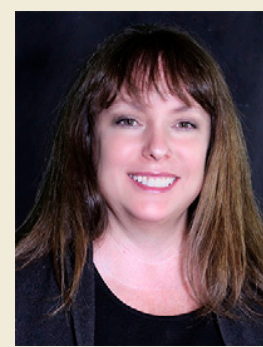

Jo Anne Crouch
Catalina Salgado is a postdoctoral research associate with the Mycology and Nematology Genetic Diversity Laboratory of the Agriculture Research Service in Beltsville, MD. She received her B.Sc. degree in biology from Universidad del Cauca, Popayán, and M.Sc. in biology from Universidad de los Andes, Bogota, Colombia. In 2014, she received a Ph.D. in plant sciences from the University of Maryland, College Park, with her doctoral work focused on the on the inference of species-level phylogenetic relationships of the genus Thelonectria (Nectriaceae) and related species with Cylindrocarpon-like anamorphs. Her current research focuses on newly emergent downy mildew and fungal pathogens of ornamental plants, using genomic tools to understand the factors underlying the recent epidemic outbreaks, evolutionary diversification, and population genetics.

Nina Shishkoff has a B.S. in botany from the University of Michigan and a Ph.D. in mycology from Cornell University. She has worked with obligate parasites (powdery mildews) since 1994, researching the taxonomy and host range of Podosphaera xanthii, the mildew causing powdery mildew of squash and melons. She studied their pesticide resistance, mating behavior, and biological control as a research associate at Cornell's Long Island Horticultural Research and Extension Center in Riverhead, NY, also doing work on Phytophthora capsici on pumpkin and Pythium in greenhouse settings. When she joined the USDA Agricultural Research Service, her main research goal was to investigate the implications for eastern nurseries of the spread of sudden oak death disease from the western U.S. Since 2013, she has been studying the downy mildew attacking Impatiens plants.

Margery Daughtrey is a senior extension associate with the Section of Plant Pathology and Plant-Microbe Biology of Cornell University. She has conducted a research and extension program on the management of diseases of ornamental plants since 1978, at Cornell's Long Island Horticultural Research and Extension Center in Riverhead, NY. She educates growers on management of greenhouse and nursery crop diseases, runs a diagnostic laboratory, and investigates controls for problems such as powdery mildew, impatiens downy mildew, and boxwood blight. Daughtrey holds a B.S. degree in biology from the College of William and Mary and an M.S. in plant pathology from the University of Massachusetts. She was named a Fellow of APS in 2012. Daughtrey is coauthor of several books, including Diseases of Herbaceous Perennials and the Compendium of Flowering Potted Plant Diseases, as well as the new Compendium of Bedding Plant Diseases and Pests, published by APS Press in summer 2018.

Cristi Palmer is the Environmental Horticulture Program Manager at the Inter-Regional Project \#4 (IR-4) based at Rutgers University (Princeton, NJ). She coordinates cross-institutional efficacy and crop safety research on biological and chemical active ingredients to facilitate registration of new products and update existing labels so that environmental horticulture growers can manage diseases, pests, and weeds in and around their crops. She also coordinates special research projects for invasive species (boxwood blight, chrysanthemum white rust, gladiolus rust, impatiens downy mildew, and exotic arthropods) and for pollinator protection in environmental horticulture, collaborating with 50 to 60 scientists and 25 to 30 registrants annually. She received her master's degree in plant pathology from the University of Florida and completed her Ph.D. in horticultural plant pathology at Cornell University studying the impact of potassium bicarbonate on Botrytis cinerea infecting geraniums.

Jo Anne Crouch is a research molecular biologist with USDAARS in Beltsville, MD, where she leads research programs on the diversity, detection, identification, and systematics of new and emerging plant pathogenic fungi and oomycetes. In recent years, her research efforts have focused on emergent diseases affecting floriculture and nursery crops, such as boxwood blight, and downy mildews affecting impatiens and other high-value floriculture plants. She also works extensively with turfgrass diseases, including anthracnose, dollar spot, and rusts. Dr. Crouch received her bachelor's degree in plant science at Rutgers University in 2002, and her Ph.D. in plant biology and pathology from the same university in 2008 .
Lu, M., An, H., and Li, L. 2016. Genome survey sequencing for the characterization of the genetic background of Rosa roxburghii Tratt and leaf ascorbate metabolism genes. PLoS One 11:e0147530.

Nakamura, N., Hirakawa, H., Sato, S., Otagaki, S., Matsumoto, S., Tabata, S., and Tanaka, Y. 2017. Genome structure of Rosa multiflora, a wild ancestor of cultivated roses. DNA Res. 25:113-121.

O'Neill, T. M., Pye, D., and Locke, T. 2002. The effect of fungicides, irrigation and plant density on the development of Peronospora sparsa, the cause of downy mildew in rose and blackberry. Ann. Appl. Biol. 140:207-214.

Palmer, C., and Vea, E. 2016. Downy mildew fungicide efficacy. IR-4 Ornamental Horticulture Program. http://ir4.rutgers.edu/Ornamental/SummaryReports/ DownyMildewDataSummary2016.pdf

Quiroga, N. J., and Arbeláez, G. 2004. Evaluation of the effectiveness of fungicides applied to the soul and to the foliage for control of downy mildew caused by Peronospora sparsa in a commercial rose farm. Agron. Colomb. 22:110-118

Reuveni, R., and Raviv, M. 1997. Control of downy mildew in greenhouse-grown cucumbers using blue photoselective polyethylene sheets. Plant Dis. 81: 999-1004.

Rivera, Y., Salgado-Salazar, C., Gulya, T., and Crouch, J. A. 2016. Newly emerged populations of Plasmopara halstedii infecting rudbeckia exhibit unique genotypic profiles and are distinct from sunflower-infecting strains. Phytopathology 106:752-761
Rodríguez-Díaz, K. J., Silva-Rojas, H. V., Boyzo-Marin, J., Segura-Ledesma, S. D., Leyva-Mir, S. G., and Rebollar-Alviter, A. 2017. Molecular detection of Peronospora sparsa in sources of primary inoculum and components of resistance in wild blackberry species. Eur. J. Plant Pathol. 149:845-851.

Salgado-Salazar, C., Ismaiel, A., and Crouch, J. A. 2018. First report of downy mildew of Double Knock Out rose caused by Peronospora sparsa in Maryland. Plant Dis. 102:1464.

Schulz, D. F., and Debener, T. 2007. Screening for resistance to downy mildew and its early detection in roses. Acta Hortic.: 189-198.

Schulz, D. F., and Debener, T. 2009. Downy mildew in roses: strategies for control. Acta Hortic. 870:163-170.

Skalicky, V. 1966. Taxonomie der gattungen der familie Peronosporaceae. Preslia 38:117-129.

Soto, L. C., and Filgueira, J. J. 2009. Effect of photoperiod and light intensity on the sporulation of Peronospora sparsa Berkeley under controlled environmental conditions. Agron. Colomb. 27:245-251.

Spring, O. 2000. Homothallic sexual reproduction in Plasmopara halstedii, the downy mildew of sunflower. Helia 32:19-26.

Sukanya, S. L., and Spring, O. 2013. Influence of temperature and ultra-violet light on viability and infectivity of Peronospora tabacina sporangia. Crop Prot. 51: 14-18.

Suthaparan, A., Stensvand, A., Solhaug, K. A., Mortensen, L. M., Gadoury, D. M., Seem, R. C., and Gislerod, H. R. 2012. Suppression of powdery mildew 
(Podosphaera pannosa) in greenhouse roses by brief exposure to supplemental UV-B radiation. Plant Dis. 96:1653-1660.

Telle, S., and Thines, M. 2008. Amplification of cox2 (620 bp) from $2 \mathrm{mg}$ of up to 129 years old herbarium specimens, comparing 19 extraction methods and 15 polymerases. PLoS One 3:e3584.

Thines, M., and Choi, Y.-J. 2016. Evolution, diversity, and taxonomy of the Peronosporaceae, with focus on the genus Peronospora. Phytopathology 106:6-18.

USDA-NASS. 2016. Floriculture Crops 2015 Summary. http://usda.mannlib. cornell.edu/usda/current/FlorCrop/FlorCrop-04-26-2016.pdf

Varila, D. 2005. Evaluación de la respuesta a la temperatura de siete Peronospora sparsa provenientes de cultivos comerciales de rosa de la Sabana de Bogotá [Undergraduate Dissertation]. Facultad de Agronomía, Universidad Nacional de Colombia, Bogotá, Colombia.

Verkley, G., Rossman, A. Y., and Crouch, J. A. 2015. The role of herbaria and culture collections. Pages 205-225 in: The Mycota VII: Systematics and Evolution, Part B. 2nd edition. D. J. McLaughlin and J. W. Spatafora, eds. Springer-Verlag, Berlin.
Virányi, F. 1985. A simple technique for long-term storage of Plasmopara halstedii sporangia at low temperature. Trans. Br. Mycol. Soc. 85:529-531.

Williamson, B., Cooke, D. E. L., Duncan, J. M., Leifert, C., Breese, W. A., and Shattock, R. C. 1998. Fungal infections of micropropagated plants at weaning: a problem exemplified by downy mildews in Rubus and Rosa. Plant Cell Tissue Organ Cult. 52:89-96.

Windham, M. T., and Windham, A. S. 2014. Downy Mildew of Rose. American Nurseryman May:16-17.

Wong, F. P., Burr, H. N., and Wilcox, W. F. 2001. Heterothallism in Plasmopara viticola. Plant Pathol. 50:427-432.

World Floriculture Map. 2016. Rabobank. https://research.rabobank.com/far/en/ sectors/regional-food-agri/world_floriculture_map_2016.html

$\mathrm{Xu}, \mathrm{X}$.-M., and Pettitt, T. 2004. Overwintering of rose downy mildew (Peronospora sparsa). Pages 99-106 in: Advances in Downy Mildew Research. Volume 2. P. Spencer-Phillips and M. Jeger, eds. Kluwer Academic Publishers, Dordrecht, The Netherlands. 